\title{
Cellular and Molecular Mechanisms in Vascular Smooth Muscle Cells by which Total Saponin Extracted from Tribulus Terrestris Protects Against Artherosclerosis
}

\author{
Mengquan Lia Yue Guan ${ }^{\mathrm{b}}$ Jiaqi Liu ${ }^{\mathrm{a}}$ Fengguo Zhaia Xiuping Zhang ${ }^{\mathrm{a}}$ \\ Lixin Guan $^{a}$ \\ aDepartment of Pharmacology, Mudanjiang Medical University, Mudanjiang, ${ }^{\mathrm{b}}$ Department of \\ Endocrinology and Metabolism, Hongqi Hospital of Mudanjiang Medical University, Mudanjiang, P.R. \\ China
}

\section{Key Words}

Tribulus terrestris • Saponin • Atherosclerosis • Vascular Smooth Muscle Cells • Proliferation • Mechanisms

\begin{abstract}
Background/Aims: Total saponin extracted from Tribulus terrestris (TSETT) has been reported to protect against atherosclerosis. We here investigate the cellular and molecular mechanisms of TSETT underlying protection against atherosclerosis. Methods: Cell proliferation was measured with Methyl thiazolyl tetrazolium (MTT); Intracellular $\mathrm{H}_{2} \mathrm{O}_{2}$ was measured with DCFH$\mathrm{DA}$, a fluorescent dye; Intracellular free $\mathrm{Ca}^{2+}$ was measured with a confocal laser scanning microscopy; Genes expression was measured with gene array and real-time quantitative polymerase chain reaction (RT-PCR); Phosphorylation of extracellular signal-regulated kinase 1/2 (phospho-ERK1/2) was measured with cell-based enzyme-linked immunosorbent assay (ELISA) and western blotting. Results: TSETT significantly suppressed the increase in cells proliferation induced by angiotensin II, significantly suppressed the increase in the intracellular production of $\mathrm{H}_{2} \mathrm{O}_{2}$ induced by angiotensin II, significantly inhibited the increase in intracellular free $\mathrm{Ca}^{2+}$ induced by $\mathrm{H}_{2} \mathrm{O}_{2}$, significantly inhibited the increase in phospho-ERK1/2 induced by angiotensin II; significantly inhibited the increase in mRNA expression of $c$-fos, $c$-jun and $p k c-\alpha$ induced by angiotensin II. Conclusion: These findings provide a new insight into the antiatherosclerotic properties of TSETT and provide a pharmacological basis for the clinical application of TSETT in anti-atherosclerosis.
\end{abstract}




\section{Introduction}

Tribulus terrestris L. (Zygophyllaceae) is an annual creeping herb that grows widely in China [1]. Total saponin extracted from Tribulus terrestris (TSETT) has been reported to protect against the formation of atherosclerosis [2]. However, little is known about the cellular and molecular mechanisms by which TSETT alleviates atherosclerosis.

Vascular smooth muscle cells (VSMCs) proliferation induced by various growth factors contributes to a variety of pathological processes including atherosclerosis [3]. Angiotensin II, an octapeptide hormone, is the active component of the renin-angiotensin system and acts as a potent growth factor for VSMCs. As a classical second messenger and an important signalling molecule, intracellular free $\mathrm{Ca}^{2+}\left(\left[\mathrm{Ca}^{2+}\right]_{\mathrm{i}}\right)$ has been reported to be involved in the VSMCs proliferation induced by angiotensin II [4]. Reactive oxygen species (ROS) as mediators of angiotensin II act on calcium signaling [5]. Subsequently, a growing body of evidence suggests that protein kinase C (PKC), extracellular signal-regulated kinase $1 / 2$ (ERK1/2) and some immediate-early proto-oncogenes, such as $c$-fos and $c$-jun, are involved in the proliferation of VSMCs induced by angiotensin II [6-9].

In the study reported herein, we aimed to elucidate the cellular and molecular mechanisms by which TSETT alleviates atherosclerosis. We investigated the effect of TSETT on angiotensin II-induced proliferation in cultured VSMCs and analysed the involvement of ROS, $\left[\mathrm{Ca}^{2+}\right]_{\mathrm{i}}, c-f o s, c-j u n, p k c-\alpha$ and ERK1/2.

\section{Materials and Methods}

\section{Preparation of TSETT}

Air-dried and powdered fruits of Tribulus terrestris ( $240 \mathrm{~g}$ ) were extracted three times with $70 \%$ ethanol. The combined extracts were evaporated to dryness under vacuum. The residue was dissolved in water and extracted by aqueous n-Butanol three times. The n-Butanol extract was evaporated to dryness under vacuum and was subjected to chromatography on D101 resin, and first eluted successively with water and then with 50\%, 70\% and 100\% ethanol. Fractions containing saponins were combined and then evaporated to dryness under reduced pressure to give the TSETT (yield $0.261 \%$ ). TSETT sample was dissolved in phosphate buffered saline (PBS) and sterilized by passing through a $0.22 \mu \mathrm{m}$ syringe filter.

\section{Cell Culture}

Primary VSMCs were obtained from the thoracic aorta of newborn calves and cultured by the tissue explant method as described in our previous paper [10]. Briefly, the smooth muscle tissue was opened longitudinally, cut into small pieces, transferred into $75-\mathrm{cm}^{2}$ flasks, and maintained at $37^{\circ} \mathrm{C}$ in a humidified incubator with an atmosphere of $95 \%$ air and $5 \% \mathrm{CO}_{2}$. Tissue explants were cultured in Dulbecco's Modified Eagle's Medium (DMEM) (Invitrogen, Carlsbad, CA, USA) that contained 20\% Fetal Bovine Serum (FBS) (Invitrogen), $100 \mathrm{u} / \mathrm{ml}$ penicillin and $100 \mu \mathrm{g} / \mathrm{ml}$ streptomycin. The cells that grew from the explants reached confluence after approximately 14 days and were subcultured with $0.25 \%$ trypsin (Sigma, St. Louis, MO, USA) to fresh flasks. After the first subculture, the cells were subcultured every 3 to 4 days. From the first subculture, the medium was changed to DMEM that contained 10\% FBS and the antibiotics. Cells were characterised as VSMCs on the basis of a hill-and-valley growth pattern displayed at confluence and by positive immunostaining with a monoclonal antibody against VSMC-specific $\alpha$-actin (Santa Cruz, CA, USA). Cells at passages $3-5$ were used for the experiments.

\section{MTT Assay for VSMCs Proliferation}

We assessed metabolic activity of cells using an assay based on the reduction of Methyl thiazolyl tetrazolium (MTT), the tetrazolium salt, by cellular metabolism. Bioreduction of tetrazolium salts probably reflects the integrated pyridine nucleotide dependent redox state of the cell. Therefore, the amount of formazan product is proportional to the metabolic activity of cells in culture and provides a widely used, although indirect, measurement of cell proliferation. Briefly, a suspension of VSMCs was diluted to $5 \times 10^{4}$ cells $/ \mathrm{ml}$ in medium that contained $10 \%$ FBS and seeded into 96-well culture plates. After $24 \mathrm{~h}$, the 
Li et al.: Mechanisms in VSMCs of Tribulus Terrestris Underlying Protection Against Atherosclerosis

medium was exchanged for DMEM that contained 0.5\% FBS to make the cells quiescent for $48 \mathrm{~h}$. Cells were preincubated in the presence or absence of TSETT or losartan which served as a positive control, and then stimulated with angiotensin II (Sigma) in DMEM that contained 0.5\% FBS. Further wells had cells which were cultured in medium without any stimulation, and these served as negative controls. Six duplicate wells were set up for each condition. At the end of stimulation period, the culture medium was exchanged for medium that contained $0.5 \mathrm{mg} / \mathrm{ml}$ MTT (Sigma), and the cells were incubated at $37^{\circ} \mathrm{C}$ for $4 \mathrm{~h}$. Formazan crystals were dissolved in $150 \mu \mathrm{l}$ of dimethyl sulfoxide. Absorbance at $490 \mathrm{~nm}$ was measured with a 96-well plate reader (Thermo Electron 1500; Thermo Electron Corp., Waltham, MA, USA) to quantify the amount of formazan product, which reflects the number of cells in culture. Wells that did not contain cells were used as a zero point of absorbance. Each assay was performed three times.

\section{Determination of $\mathrm{H}_{2} \mathrm{O}_{2}$ Production in VSMCs}

The generation of intracellular $\mathrm{H}_{2} \mathrm{O}_{2}$ was monitored with DCFH-DA (2',7'-dichlorofluorescein diacetate), a fluorescent dye, which was dialyzed into the cells. The fluorescence signal was measured with a multilabel plate counter $\left(1420\right.$ VICTOR $\left.^{2}\right)$. Specifically, a suspension of VSMCs was diluted to $5 \times 10^{4}$ cells $/ \mathrm{ml}$ in medium that contained $10 \% \mathrm{FBS}$ and seeded into 96 -well culture plates. After $24 \mathrm{~h}$, the medium was exchanged for DMEM that contained 0.5\% FBS to make the cells quiescent. Confluent cells were preincubated with or without TSETT. Then incubated with $10^{-5} \mathrm{M}$ of DCFH-DA (Molecular Probes) for 30min, followed by stimulation with angiotensin II for $5 \mathrm{~min}$. Cells were lysed with $0.5 \mathrm{M}$ of $\mathrm{NaOH}$. The fluorescence was measured at $485 \mathrm{~nm}$ excitation and $525 \mathrm{~nm}$ emission. Six duplicate wells were set up for each condition. Each assay was performed in triplicate.

\section{Measurement of $\left[\mathrm{Ca}^{2+}\right]_{i}$ by Confocal Laser Scanning Microscopy}

$\left[\mathrm{Ca}^{2+}\right]_{\mathrm{i}}$ was measured using the calcium fluorescence indicator fluo-3-AM (Molecular Probes Inc. Eugene, Oregon, USA) which was dialyzed into the cells. The fluorescence signal was monitored with confocal laser scanning microscopy (LSM 510; Carl Zeiss, Jena, Germany). Specifically, cells adherent to coverslips were preincubated with or without TSETT for $30 \mathrm{~min}$, then washed three times with HEPES buffer that contained $1.5 \mathrm{mM} \mathrm{CaCl}_{2}$ and incubated with $5 \mathrm{mM}$ fluo-3-AM for $20 \mathrm{~min}$ at $37^{\circ} \mathrm{C}$ in $5 \% \mathrm{CO}_{2}$. Extracellular fluo-3-AM was removed by washing the cells three times in HEPES-buffered saline. Imaging was performed using a Zeiss LSM image browser. The fluo-3 dye was excited with a $488 \mathrm{~nm}$ wavelength argon laser beam and the emission fluorescence was monitored at $525 \mathrm{~nm}$. Hydrogen peroxide $\left(\mathrm{H}_{2} \mathrm{O}_{2}\right)$ stimulation was added during scanning. Relative fluorescence intensity was quantified using the regions of interest (ROI) tool of the 'time course' software on the LSM image browser system and displayed as arbitrary units after subtraction of the background ROI.

\section{Gene Array Assay}

Total cellular RNA from VSMCs was isolated using TRIzol reagent (Invitrogen) in accordance with the manufacturer's protocol. The purity and integrity of RNA were determined by the absorbance at $A_{260 / 280}$ and gel electrophoresis, respectively. The RNA with $A_{260 / 280}>1.9$ was used for synthesis of cDNA probes. cDNA probes were synthesized using GEArray-specific primers and Moloney murine leukaemia virus reverse transcriptase (Promega Co., Madison, WI, USA) in the presence of RNase inhibitor (Promega); Biotin-16dUTP (Roche Applied Science, Indianapolis, IN, USA) was also included in the reaction. Gene arrays were prehybridised with sheared salmon sperm DNA (Invitrogen) before hybridisation with the cDNA probes. Hybridisation was carried out at $60^{\circ} \mathrm{C}$ for $16 \mathrm{~h}$. Chemiluminescent images of the gene arrays were recorded on X-ray film. ScanAlyze software (SuperArray Inc., Bethesda, MD, USA) was used to analyse optimally exposed radiographs. The abundance of each transcript was normalised to the abundance of housekeeping gene markers on each array.

\section{Real-time Quantitative PCR}

Real-time quantitative polymerase chain reaction (Real-time quantitative PCR) was used to verify the differential expressions of the selected genes. Total RNA preparation was described as above. Primers were designed by using Primer Express Software, version 5 (Applied Biosystems, Inc., Foster City, CA). The primers for $c$-fos were 5'-GTG CCAACT TCA TCC CAACA-3' (sense) and 5'-GCA GCC ATC TTA TTC CTT TCC-3' (antisense) with a PCR product of $283 \mathrm{bp}$. The primers for $c$-jun were 5'-ACG ACC TTC TAT GAC GAT GCC-3' (sense) and 
Li et al.: Mechanisms in VSMCs of Tribulus Terrestris Underlying Protection Against Atherosclerosis

5'-CCC GTT GCT GGA CTG TAT GA-3' (antisense) with a PCR product of $240 \mathrm{bp}$. The primers of upstream and downstream for $p k c$ - $\alpha$ were 5'-GGGAATGTTACCTGTTTCTGCT-3' and 5'-GGTCACTGTAAGGCTGTTGGAT-3', respectively, and the product was $250 \mathrm{bp}$ long. The housekeeping gene glyceraldehyde-3-phosphate dehydrogenase (GAPDH) was used as an internal control. The primers of upstream and downstream for GAPDH were 5'-AAGAAGGTGGTGAAGCAGGC-3' and 5'-TCCACCACCCTGTTGCTGTA-3', respectively, and the product was 203 bp long. Real-time quantitative PCR was carried out with the Light Cycler Instrument (Roche Applied Science) using the DNA binding dye SYBR Green I for detection of PCR products. PCR was performed in multiplicate in optimized conditions: $95^{\circ} \mathrm{C}$ denatured for $5 \mathrm{~min}$, followed by multiple cycles at $95^{\circ} \mathrm{C}$ for $10 \mathrm{~s}$, at $58^{\circ} \mathrm{C}$ for $15 \mathrm{~s}$, at $72^{\circ} \mathrm{C}$ for $20 \mathrm{~s}$, and $85^{\circ} \mathrm{C}$ for $5 \mathrm{~s}$ (collecting fluorescence). For $c$ - fos, $c$-jun and $p k c-\alpha$, the cycle number was 35 and for GAPDH, the cycle number was 30 , then $72^{\circ} \mathrm{C}$ for $10 \mathrm{~min}$, followed by melting curve analysis. Standard curves for these molecules were generated by amplifying 1-, 10-, 100-, 1000-, and 10000-fold dilutions of murine macrophage cDNA. The mRNA level for each sample was normalised to that of GAPDH.

\section{Cell-based ELISA for ERK1/2 Phosphorylation}

A suspension of VSMCs was diluted to $5 \times 10^{4}$ cells $/ \mathrm{ml}$ in medium that contained $10 \%$ FBS and seeded into 96-well culture plates. After $24 \mathrm{~h}$, the medium was exchanged for DMEM that contained $0.5 \%$ FBS to make the cells quiescent for $4 \mathrm{~h}$. VSMCs were preincubated for $30 \mathrm{~min}$ in the presence or absence of TSETT or losartan which served as a positive control, and then stimulated with angiotensin II for 10 min in DMEM that contained $0.5 \%$ FBS. Further wells had cells which were cultured in medium without any stimulation, and these served as negative controls. Six duplicate wells were set up for each condition. Phosphorylation of ERK1/2 (phospho-ERK1/2) was measured by cell-based enzyme-linked immunosorbent assay (ELISA) as described previously [11]. Briefly, after stimulation, the cells were fixed with $4 \%$ paraformaldehyde in PBS at room temperature for $20 \mathrm{~min}$ and washed three times with PBS that contained $0.1 \%$ Triton X-100 (PBS/ Triton). Endogenous peroxidase was quenched with $0.6 \% \mathrm{H}_{2} \mathrm{O}_{2}$ in PBS/Triton for $20 \mathrm{~min}$. After had been washed for three times with PBS/Triton, the cells were blocked with 10\% FBS in PBS/Triton for $1 \mathrm{~h}$ and at $4^{\circ} \mathrm{C}$ incubated overnight with primary antibody against phospho-ERK1/2 (Santa Cruz). The following day, cells were washed three times with PBS/Triton and incubated with horseradish peroxidase-coupled goat anti-mouse IgG antibody (Santa Cruz) at room temperature for $1 \mathrm{~h}$, and washed three times with PBS/Triton and twice with PBS. Subsequently, cells were incubated with $50 \mu \mathrm{l}$ of a solution that contained $0.6 \mathrm{mg} / \mathrm{ml}$ 3, 3'-diaminobenzidine and $0.03 \% \mathrm{H}_{2} \mathrm{O}_{2}$ in PBS at room temperature in dark for $15 \mathrm{~min}$. The reaction was stopped with $25 \mu \mathrm{l}$ of $1 \mathrm{M} \mathrm{H}_{2} \mathrm{SO}_{4}$, and $\mathrm{A}_{490}$ was measured with an ELISA reader (1500: Thermo Electron Corp.) to quantify the amount of phospho-ERK1/2. Wells that did not contain cells were used as a zero point of absorbance. Each assay was performed in triplicate.

\section{Western Blotting Analysis}

Confluent cells were preincubated with or without TSETT, followed by stimulation with angiotensin II. Subsequently, cells were washed twice with ice-cold PBS containing $1 \mathrm{mM} \mathrm{Na}_{3} \mathrm{VO}_{4}$ and $1 \mathrm{mM} \mathrm{NaF}$, and then lysed by the addition of $200 \mu$ ice-cold lysis buffer containing $50 \mathrm{mM}$ Tris, $\mathrm{pH} 7.5,150 \mathrm{mM} \mathrm{NaCl}, 2 \mathrm{mM}$ EDTA, $1 \mathrm{mM}$ EGTA, 1\% Triton X-100, $50 \mathrm{mM} \mathrm{NaF}, 1 \mathrm{mM} \mathrm{Na}_{3} \mathrm{VO}_{4}, 1 \mathrm{mM}$ phenylmethylsulfonyl fluoride (PMSF), and $10 \mu \mathrm{g} / \mathrm{ml}$ leupeptin. The cell lysates were then incubated on ice for $30 \mathrm{~min}$, scraped and transferred into a $1.5 \mathrm{ml}$ Eppendorf tube. After brief sonication, the samples were centrifuged for $15 \mathrm{~min}$ at $14,000 \times \mathrm{g}$ at $4^{\circ} \mathrm{C}$. Supernatants were used immediately or stored at $-70{ }^{\circ} \mathrm{C}$. Protein concentrations were determined by the Bradford method using bovine serum albumin (BSA) as a standard.

Equal amounts of proteins were subjected to SDS-polyacrylamide gel electrophoresis (PAGE) (10\% separating gel and 5\% stacking gel). After electrophoresis, the proteins were transferred to nitrocellulose membranes by electrotransfer. Membranes were blocked in $5 \%$ nonfat milk powder in Tris-buffered saline (TBS)/0.1\% Tween-20 for $1 \mathrm{~h}$ at room temperature, and then incubated for $2 \mathrm{~h}$ at $37{ }^{\circ} \mathrm{C}$ with specific antibodies (Santa Cruz). Membranes were subsequently washed three times and incubated in horseradish peroxidase-coupled anti-mouse IgG antibody for $1 \mathrm{~h}$ at room temperature. Immunoreactive bands were visualized by an enhanced chemiluminesence assay following the manufacturer's instructions (Pierce Biotechnology Inc., Rockford, USA). Bands intensities were measured by computer analysis, using the BioRad Quantity One 4.5.1 software. 
Li et al.: Mechanisms in VSMCs of Tribulus Terrestris Underlying Protection Against Atherosclerosis

Fig. 1. Effect of TSETT on angotensin II-induced VSMCs proliferation. Cells proliferation was measured using MTT assay. The result was shown in Fig. 1A. (A), negative control: Cells were cultured in medium without any stimulation; (B), angiotensin II samples: Cells were stimulated with angiotensin II (100 nM) for $24 \mathrm{~h}$; (C), (D), (E) and (F), TSETT and losartan samples: Cells were preincubated for $12 \mathrm{~h}$ with TSETT $(0.060,0.120,0.240 \mathrm{mg} / \mathrm{ml})$ and losartan $(1 \mu \mathrm{M})$, respectively, followed by stimulation with angiotensin II (100 nM) for 24 h. Data are expressed as mean \pm SD $(n=6) .{ }^{* *} p$ $<0.01$, significant difference from the negative control; \# $p<0.05$, \#\# $p<0.01$, significant difference from the angiotensin II samples. The time course of TSETT effect was shown in Fig. 1B. (a): Cells were cultured in medium for different time without any stimulation; (b): Cells were stimulated with angiotensin II (100 nM) for different time; (c): Cells were cultured in medium with TSETT $(0.240 \mathrm{mg} / \mathrm{ml})$ for different time; (d): Cells were preincubated with TSETT $(0.240 \mathrm{mg} / \mathrm{ml})$ for different time followed by stimulation with angiotensin II (100 $\mathrm{nM}$ ) for $24 \mathrm{~h}$.

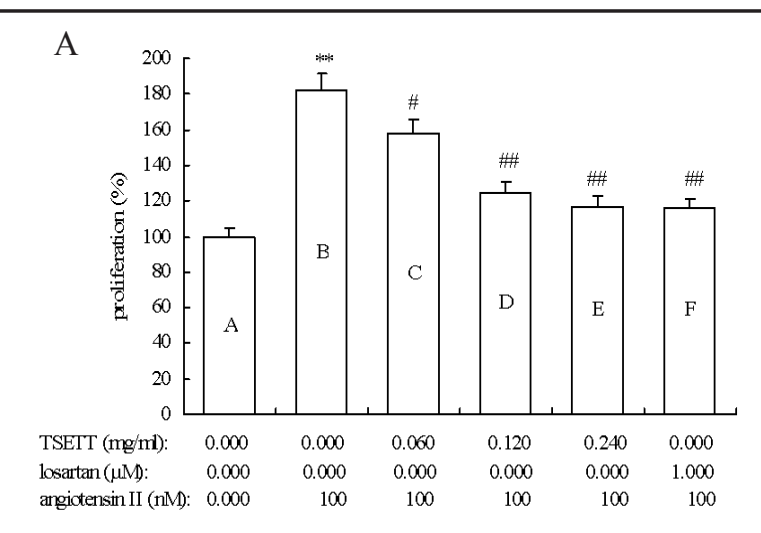

B

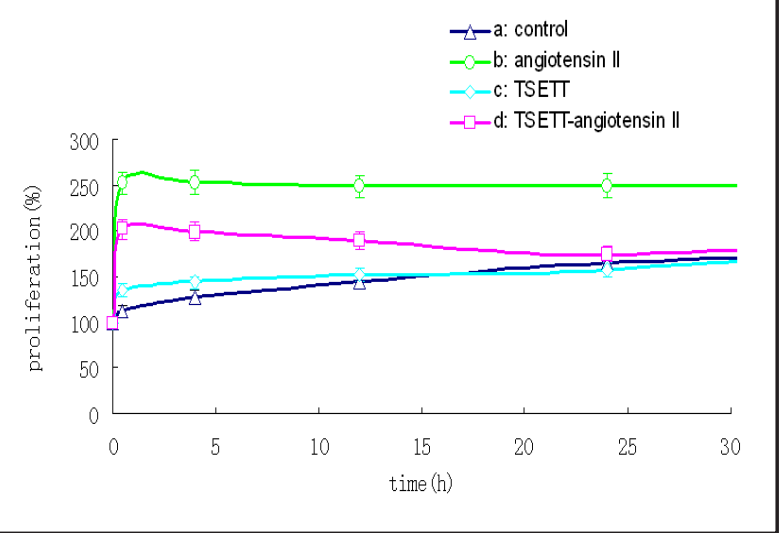

\section{Statistical Analysis}

Data are expressed as the mean \pm standard deviation (SD). Statistical differences between mean values were determined using one-way analysis of variance and Student's $t$ test. $P \leq 0.05$ was considered statistically significant.

\section{Results}

Effect of TSETT on Angiotensin II-induced VSMCs Proliferation

Proliferation was examined by MTT as described in "Materials and methods". Referring to the concentration-effect relationship [12], three concentrations of TSETT were designed as $0.060,0.120$ and $0.240 \mathrm{mg} / \mathrm{ml}$. VSMCs were preincubated for $12 \mathrm{~h}$ with or without TSETT, and then stimulated with angiotensin II $(100 \mathrm{nM})$ in DMEM that contained $0.5 \%$ FBS for 24 h. The result was shown in Fig. 1A. In comparison with negative control (A), angiotensin II (100 nM) stimulated VSMCs proliferation significantly (B). The proliferation of the unstimulated cells was not affected by TSETT (data not shown). However, angiotensin IIinduced VSMCs proliferation was suppressed by TSETT at 0.060(C), 0.120(D) and 0.240(E) $\mathrm{mg} / \mathrm{ml}$ in a concentration-dependent manner. The maximal suppressive effect was at 0.240 $\mathrm{mg} / \mathrm{ml}$. This concentration was therefore used in the following experiments. $1 \mu \mathrm{M}$ losartan (Mediking Pharmaceutical Co. Ltd., Beijing, China), an angiotensin II receptor antagonist drug used mainly to treat high blood pressure (hypertension), which served as a positive control, significantly suppressed angiotensin II-induced VSMCs proliferation (F).

The time-course of TSETT effect was shown in Fig. 1B. The cell proliferation in negative control group increased slightly (a). After stimulated by $100 \mathrm{nM}$ angiotensin II, the cell proliferation increased rapidly (b), peaked at $30 \mathrm{~min}$, and remained at higher level than 
Li et al.: Mechanisms in VSMCs of Tribulus Terrestris Underlying Protection Against Atherosclerosis

Fig. 2. Effect of TSETT on angiotensin IIinduced intracellular $\mathrm{H}_{2} \mathrm{O}_{2}$ generation and $\mathrm{H}_{2} \mathrm{O}_{2}$-induced $\left[\mathrm{Ca}^{2+}\right]_{\mathrm{i}}$ mobilization. Fig. 2A. showed the effect of TSETT on angiotensin IIinduced intracellular $\mathrm{H}_{2} \mathrm{O}_{2}$ generation. Cells were preincubated with or without TSETT $(0.240 \mathrm{mg} / \mathrm{ml})$ for $12 \mathrm{~h}$, then incubated with DCFH-DA $\left(10^{-5} \mathrm{M}\right)$ for $30 \mathrm{~min}$. After stimulation with angiotensin II (100 nM) for $5 \mathrm{~min}$, cells were lysed with $\mathrm{NaOH}$ (0.5 M). Fluorescence intensity was measured by 1420 multilabel counter. Results were expressed as percentages of the fluorescence intensity of quiescent cells. Data are expressed as mean \pm SD $(n=6) .{ }^{* *} p<0.01$ vs control $(A) ;{ }^{\# \#}$ $\mathrm{p}<0.01$ vs angiotensin II group (C). Fig. 2B. showed the effect of TSETT on $\mathrm{H}_{2} \mathrm{O}_{2}$-induced $\left[\mathrm{Ca}^{2+}\right]_{\mathrm{i}}$ mobilization. $\left[\mathrm{Ca}^{2+}\right]_{\mathrm{i}}$ was assayed using confocal laser scanning microscopy. The stimulation of $\mathrm{H}_{2} \mathrm{O}_{2}\left(10^{-4} \mathrm{M}\right)$ is represented by the arrow in the graph. Data are expressed as mean \pm SD $(n=6)$. Curve TSETT: Direct effect of TSETT on $\mathrm{Ca}^{2+}$ mobilization; Curve $\mathrm{H}_{2} \mathrm{O}_{2}: \mathrm{H}_{2} \mathrm{O}_{2}$-induced $\left[\mathrm{Ca}^{2+}\right]_{\mathrm{i}}$ response in normal cells; Curve TSETT- $\mathrm{H}_{2} \mathrm{O}_{2}: \mathrm{H}_{2} \mathrm{O}_{2}$-induced $\left[\mathrm{Ca}^{2+}\right]_{\mathrm{i}}$ response in the cells which were pretreated with TSETT $(0.240 \mathrm{mg} / \mathrm{ml})$ for $30 \mathrm{~min}$.

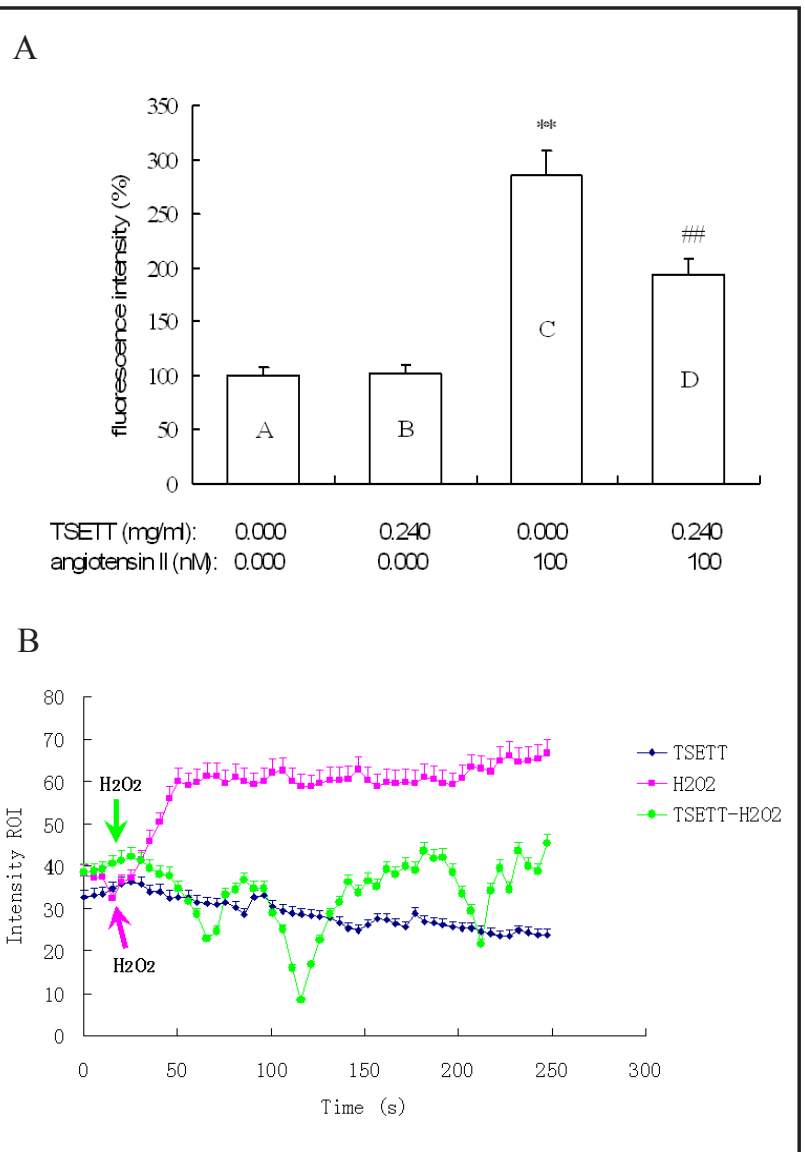

control. Incubation of the cells with TSETT $(0.240 \mathrm{mg} / \mathrm{ml})$ for different time did not affect on the un-stimulated cells (c), but inhibited the angiotensin II-induced increase of the cell proliferation (d).

Effect of TSETT on Angiotensin II-induced $\mathrm{H}_{2} \mathrm{O}_{2}$ generation and $\mathrm{H}_{2} \mathrm{O}_{2}$-induced $\left[\mathrm{Ca}^{2+}\right]_{i}$ Mobilization

We evaluated the intracellular production of $\mathrm{H}_{2} \mathrm{O}_{2}$ with DCFH-DA, a probe used to detect intracellular $\mathrm{H}_{2} \mathrm{O}_{2}$ in a variety of cells, including VSMCs. The result was shown in Fig. 2A. In comparison with control (A), the fluorescence intensity was not affected by preincubation of $0.240 \mathrm{mg} / \mathrm{ml}$ TSETT (B), but was increased significantly by the stimulation of angiotensin II $(100 \mathrm{nM})$ for $5 \mathrm{~min}(\mathrm{C})$. The increase of fluorescence intensity induced by angiotensin II was suppressed significantly by pretreatment of VSMCs with TSETT $(0.240 \mathrm{mg} / \mathrm{ml})$ for $12 \mathrm{~h}$ (D).

$\left[\mathrm{Ca}^{2+}\right]_{\mathrm{i}}$ mobilization was measured using confocal laser scanning microscopy. As shown in Fig. 2B, the overall changes in the fluorescence of the field cells being imaged were plotted over time. The stimulation of $\mathrm{H}_{2} \mathrm{O}_{2}\left(10^{-4} \mathrm{M}\right)$ was represented by the arrow in the graph. Pretreatment of VSMCs with TSETT $(0.240 \mathrm{mg} / \mathrm{ml})$ for $30 \mathrm{~min}$ did not affect the fluorescence intensity in the normal cells (TSETT). However, the fluorescence intensity in the normal cells was increased immediately by the stimulation of $\mathrm{H}_{2} \mathrm{O}_{2}$ and maintained at a higher level $\left(\mathrm{H}_{2} \mathrm{O}_{2}\right)$. The increase of the fluorescence intensity induced by $\mathrm{H}_{2} \mathrm{O}_{2}$ was blocked completely by pretreatment of VSMCs with TSETT $(0.240 \mathrm{mg} / \mathrm{ml})$ for 30 min $\left(\right.$ TSETT- $\left.\mathrm{H}_{2} \mathrm{O}_{2}\right)$. 


\section{Cellular Physiology $\quad$ Cell Physiol Biochem 2013;32:1299-1308 and Biochemistry

Fig. 3. Effects of TSETT on angiotensin II-induced gene expressions. The mRNA expressions were measured by gene array assay and real-time quantitative PCR. Fig. 3A. showed the images of mRNA expressions from gene array. Fig. 3B. showed the mRNA expressions of $c$-fos, $c$-jun and $p k c-\alpha$ from real- time quantitative PCR. Cells were preincubated with or without TSETT (240 $\mu \mathrm{g} / \mathrm{ml}$ ) for $30 \mathrm{~min}$, followed by stimulation with angiotensin II (100 $\mathrm{nM})$ for $24 \mathrm{~h}$. Further cells that were cultured in medium served as control. Three duplicate tests were set up in each sample. Data are expressed as mean \pm SD. ${ }^{*} \mathrm{p}<0.05$, ${ }^{* *} p<0.01$, significant difference from the control; \# $\mathrm{p}<0.05$, \#\# $\mathrm{p}<0.01$, significant difference from the angiotensin II samples.

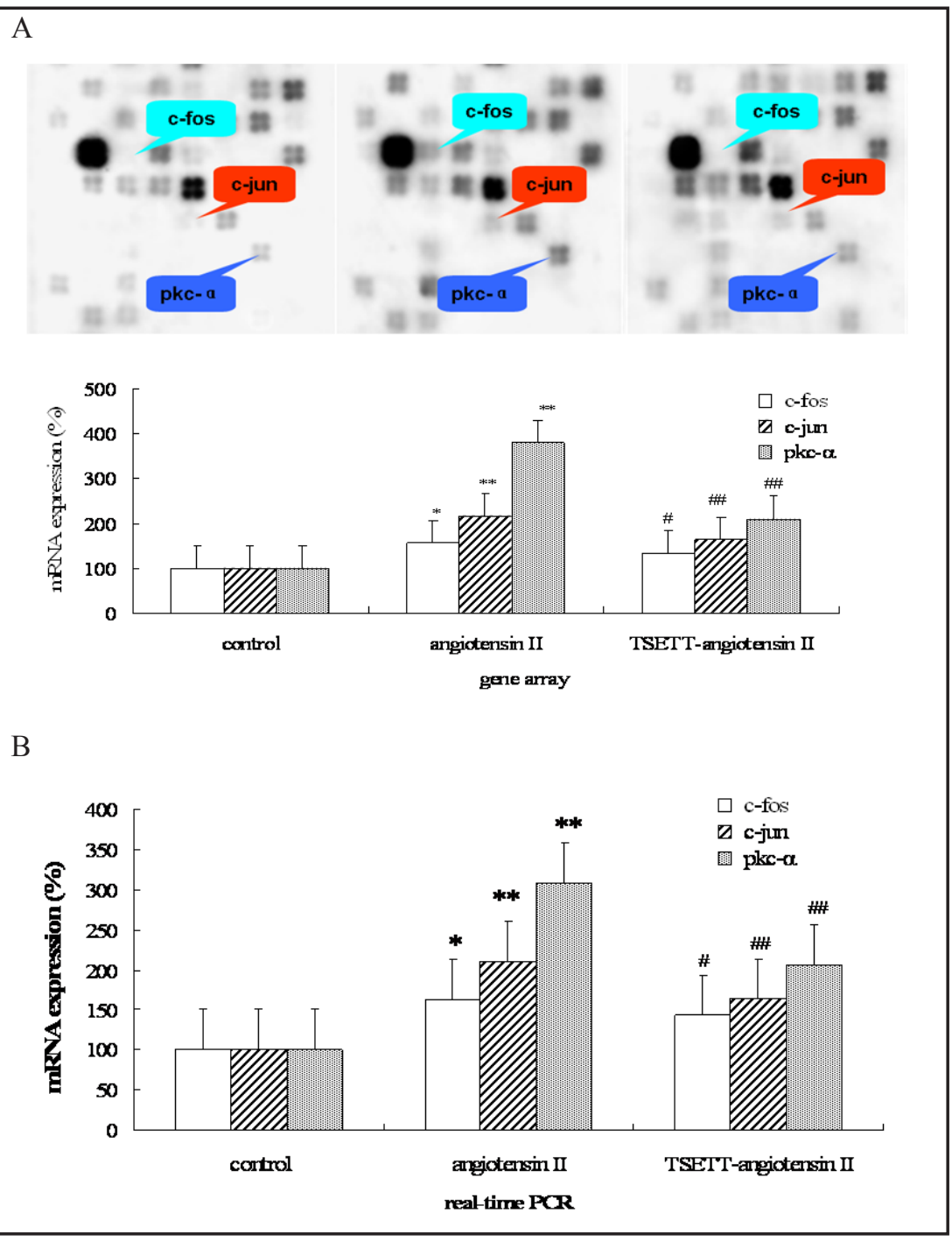

\section{Effect of TSETT on Angiotensin II-induced Gene Expressions}

Cells were preincubated in the presence or absence of TSETT $(0.240 \mathrm{mg} / \mathrm{ml})$ for $30 \mathrm{~min}$, then stimulated with angiotensin II $(100 \mathrm{nM})$ for $24 \mathrm{~h}$. Further cells which were cultured in medium served as control. At the end of the incubation period, gene expressions were determined using gene array and real-time quantitative PCR. Fig. 3A exhibited the result of gene array. In comparison with control, angiotensin II induced an obvious increase in the mRNA expression of $c$-fos, $c$-jun and $p k c-\alpha$, and the increase was inhibited by preincubation with TSETT. Whereafter, the inhibitions of $c-f o s, c$-jun and $p k c-\alpha$ were further verified by realtime quantitative PCR. As shown in Fig. 3B, the results from real-time quantitative PCR were conformable to that from gene array.

Effect of TSETT on Angiotensin II-induced ERK1/2 phosphorylation

Fig. 4A showed the effect of TSETT on angiotensin II-induced ERK1/2 phosphorylation measured with cell-based ELISA assay. In comparison with negative control (A), TSETT did not affect ERK1/2 phosphorylation in normal cells (data not shown), but angiotensin II (100 nM) stimulated ERK1/2 phosphorylation significantly (B). Angiotensin II-induced ERK1/2 phosphorylation was inhibited by TSETT of $0.060,0.120$ and $0.240 \mathrm{mg} / \mathrm{ml}$ (C, D, E) 
Li et al.: Mechanisms in VSMCs of Tribulus Terrestris Underlying Protection Against Atherosclerosis

Fig. 4. Effect of TSETT on angiotensin II-induced ERK1/2 phosphorylation. ERK1/2 phosphorylation was measured with cell- based ELISA and western blotting analysis. Fig. 4A showed cell based ELISA for phospho-ERK1/2. (A), negative control: Cells were cultured in medium without any stimulation; (B), angiotensin II samples: Cells were stimulated with angiotensin II (100 nM) for $10 \mathrm{~min}$; (C), (D), (E) and (F), TSETT and losartan samples: Cells were preincubated for $30 \mathrm{~min}$ with TSETT $(0.060,0.120,0.240 \mathrm{mg} / \mathrm{ml})$ and losartan $(1 \mu \mathrm{M})$, respectively, followed by stimulation with angiotensin II (100 nM) for $10 \mathrm{~min}$. Fig. 4B showed the result of western blotting for phospho-ERK1/2. (A), negative control: Cells were cultured in medium without any stimulation; (B): Cells were incubated only with TSETT for $12 \mathrm{~h}$; (C), angiotensin II samples: Cells were stimulated with angiotensin II (100 nM) for $5 \mathrm{~min}$; (D) and (E): Cells were preincubated for $12 \mathrm{~h}$ with TSETT of 0.120 and $0.240 \mathrm{mg} / \mathrm{ml}$, respectively, followed by stimulation with angiotensin II (100 nM) for 5 min. Data are expressed as mean $\pm S D(n=6) .{ }^{* *} p<0.01$, significant difference from the negative $\operatorname{control}(\mathrm{A})$; \# $\mathrm{p}<0.05$, \#\# $\mathrm{p}<0.01$, significant difference from the angiotensin II samples(C).

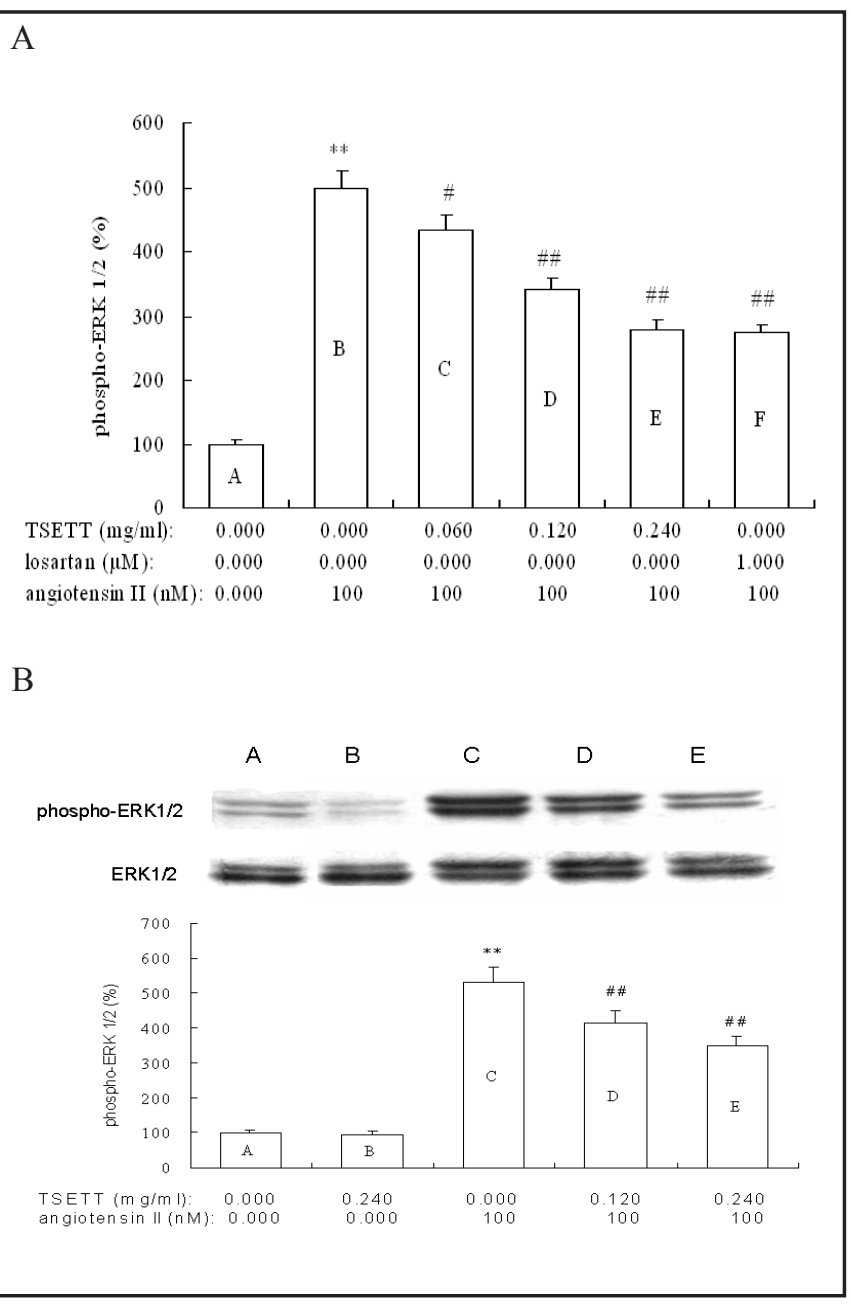

in a concentration-dependent manner. Losartan $(1 \mu \mathrm{M})$, which served as a positive control, significantly inhibited angiotensin II-induced ERK1/2 phosphorylation (F).

To confirm this result, experiments using western blotting analysis for phosphoERK1/2 were performed. As shown in Fig. 4B, band intensity of ERK1/2 was not changed after treatment with angiotensin II or/and TSETT and it was used as an internal standard. Intensity of phospho-ERK1/2 was standardized to that of ERK1/2. In comparison with negative control (A), there was no difference from the cells incubated only with TSETT (B). However, angiotensin II (100 nM) stimulated ERK1/2 phosphorylation significantly (C), and pretreatment the cells with TSETT $(0.120,0.240 \mathrm{mg} / \mathrm{ml})$ for $12 \mathrm{~h}$ resulted in a significant reduction in ERK1/2 phosphorylation induced by angiotensin II (D, E).

\section{Discussion}

It has been known that the proliferation ofVSMCs in response to angiotensin II contributes to the pathological process of atherosclerosis. In the present study, one of the more significant results was that TSETT suppressed angiotensin II-induced VSMCs proliferation. This implies that the suppression of VSMCs proliferation might be one of the cellular mechanisms by which TSETT alleviates atherosclerosis. In light of this, we further explored the molecular mechanisms underlying the suppression of TSETT on VSMCs proliferation.

The major signaling event activated by angiotensin II appears to promote the generation of ROS, such as $\mathrm{H}_{2} \mathrm{O}_{2}$, which leads to $\left[\mathrm{Ca}^{2+}\right]_{\mathrm{i}}$ mobilization $[13,14]$. Accordingly, we first 
evaluated the intracellular production of $\mathrm{H}_{2} \mathrm{O}_{2}$ with DCFH-DA. Our result demonstrated that intracellular $\mathrm{H}_{2} \mathrm{O}_{2}$ was increased significantly by the stimulation of angiotensin II and the increase was suppressed by pretreatment with TSETT. Next, we evaluated $\left[\mathrm{Ca}^{2+}\right]_{\mathrm{i}}$ with fluo-3-AM. As expected, $\left[\mathrm{Ca}^{2+}\right]_{\mathrm{i}}$ was increased sharply by stimulation with $\mathrm{H}_{2} \mathrm{O}_{2}$, and the increase was inhibited by pretreatment with TSETT. Besides, previous study also reported the antioxidant potential of TSETT [15]. These results suggest that TSETT act as a potent antioxidant to inhibit the increase in the intracellular ROS, $\left[\mathrm{Ca}^{2+}\right]_{\mathrm{i}}$ and subsequently suppress VSMCs proliferation.

PKC- $\alpha$, a conventional PKC isoform, has been shown to mediate VSMCs proliferation in rat, human and bovine $[9,16,17]$. Thus, we focused on the role of PKC- $\alpha$ in the suppression of TSETT on angiotensin II-induced VSMCs proliferation. The results showed that the mRNA expression of $p k c-\alpha$ was increased clearly by angiotensin II and the increase was inhibited significantly by pretreatment with TSETT. Moreover, the concentration of TSETT that was required for inhibition of $p k c-\alpha$ mRNA expression was similar to that required for suppression of VSMCs proliferation. So, it can be deduced that the suppressive effect of TSETT on angiotensin II-induced VSMCs proliferation is due, at least in part, to its ability to inhibit the mRNA expression of $p k c-\alpha$.

ERK1/2 is thought to function as an integrator for mitogenic signals that originate from several distinct classes of cell surface receptor, such as receptor tyrosine kinases and G-protein-coupled receptors. ERK1/2 is activated by phosphorylation on tyrosine and threonine residues, and subsequently stimulates cell proliferation [18]. We examined ERK1/2 phosphorylation to investigate whether the antiproliferative effect of TSETT is correlated with the inhibition of ERK1/2 activation. Our result showed that ERK1/2 phosphorylation was increased clearly by angiotensin II and the increase was inhibited significantly by pretreatment with TSETT. It's worth noting that fluctuations of the phosphoERK1/2 conformed to those of the cells proliferation. Therefore, the data presented here are sufficient to establish a relationship between phospho-ERK1/2 and proliferation.

Activations of PKC and ERK1/2 have been proved to induce the expression of protooncogenes, such as $c$-fos and $c$-jun, which leads to cell proliferation [19-21]. In view of these facts, we further observed the effects of TSETT on the mRNA expressions of $c$-fos and $c$-jun. Our result exhibited that the mRNA expressions of $c$-fos and $c$-jun were increased clearly by angiotensin II and the increases were inhibited significantly by pretreatment with TSETT. This result implied that the proto-oncogene mediated the suppressive effect by TSETT on the proliferation in VSMCs. In fact, previous study showed that chelerythrine chloride, a specific inhibitor of PKC, did not affect activation of ERK1/2 [9], which means that angiotensin II -induced ERK1/2 activation might be independent of PKC in VSMCs. These data suggest that the inhibition of proto-oncogene expression by TSETT attribute to the inhibitory effect on both PKC and ERK1/2.

Taken together, the present data suggest that the suppression of VSMCs proliferation induced by angiotensin II is one of the cellular mechanisms by which TSETT alleviates atherosclerosis. The possible molecular mechanisms by which TSETT suppresses VSMCs proliferation are the inhibition of the intracellular production of ROS, the inhibition of $\left[\mathrm{Ca}^{2+}\right]_{\mathrm{i}}$ mobilization, the inhibition of $p k c-\alpha$ expression, the inhibition of ERK1/2 phosphorylation, and the inhibition of proto-oncogene expression. These findings provide a new insight into the antiatherosclerotic properties of TSETT and provide a pharmacological basis for the clinical application of TSETT in anti-atherosclerosis.

\section{Acknowledgements}

This work was supported by the Key Laboratory of Cardiovascular Medicine Research (Harbin Medical University), Ministry of Education, and in part by the National Natural Science Foundation of China (30973897). 


\section{Cellular Physiology $\quad$ Cell Physiol Biochem 2013;32:1299-1308

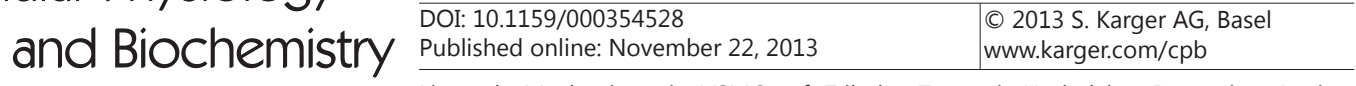 \\ Li et al.: Mechanisms in VSMCs of Tribulus Terrestris Underlying Protection Against Atherosclerosis}

\section{References}

1 Committee NP: Tribulus terrestris L. Pharmacopoeia of People's Republic of China (No.1). China Medical Science Press, Beijing, 2010, pp 330-331.

2 Shi CJ, WJ Qu, JS Wang, TT Deng: Effect of tribu saponin from Tribulus terrestris on the formation of atherosclerosis in rats. Nat Prod Res Dev 2009;21:53-57.

-3 Dzau VJ, RC Braun-Dullaeus, DG Sedding: Vascular proliferation and atherosclerosis: new perspectives and therapeutic strategies. Nat Med 2002;8:1249-1256.

-4 Touyz RM, EL Schiffrin: Signal transduction mechanisms mediating the physiological and pathophysiological actions of angiotensin II in vascular smooth muscle cells. Pharmacol Rev 2000;52:639672.

-5 Touyz RM: Reactive oxygen species as mediators of calcium signaling by angiotensin II: implications in vascular physiology and pathophysiology. Antioxid Redox Signal 2005;7:1302-1314.

Muller DW: The role of proto-oncogenes in coronary restenosis. Prog Cardiovasc Dis 1997;40:117-128. Viedt C, U Soto, HI Krieger-Brauer, J Fei, C Elsing, W Kubler, J Kreuzer: Differential activation of mitogenactivated protein kinases in smooth muscle cells by angiotensin II: involvement of p22phox and reactive oxygen species. Arterioscler Thromb Vasc Biol 2000;20:940-948.

8 Zhou CH, ZY Qian, SG Zheng, M Xiang: ERK1/2 pathway is involved in the inhibitory effect of crocetin on angiotensin II-induced vascular smooth muscle cell proliferation. Eur J Pharmacol 2006;535:61-68.

-9 Zhou CH, M Xiang, SY He, ZY Qian: Protein kinase C pathway is involved in the inhibition by crocetin of vascular smooth muscle cells proliferation. Phytother Res 2010;24:1680-1686.

10 Li M, Q Wang, L Guan: Effects of ouabain on proliferation, intracellular free calcium and c-myc mRNA expression in vascular smooth muscle cells. J Comp Physiol B 2007;177:589-595.

-11 Versteeg HH, E Nijhuis, GR van den Brink, M Evertzen, GN Pynaert, SJ van Deventer, PJ Coffer, MP Peppelenbosch: A new phosphospecific cell-based ELISA for $\mathrm{p} 42 / \mathrm{p} 44$ mitogen-activated protein kinase (MAPK), p38 MAPK, protein kinase B and cAMP-response element-binding protein. Biochem J 2000;350:717-722.

12 Yang HJ, WJ Qu, B Sun: Experimental study of saponins from Tribulus terrestris on renal carcinoma cell line. Zhongguo Zhong Yao Za Zhi 2005;30:1271-1274.

13 Griendling KK, CA Minieri, JD Ollerenshaw, RW Alexander: Angiotensin II stimulates NADH and NADPH oxidase activity in cultured vascular smooth muscle cells. Circ Res 1994;74:1141-1148.

14 Zhou CH, ZY Qian, M Xiang, SY He: Involvement of $\mathrm{Ca}^{2+}$ in the inhibition by crocetin of angiotensin IIinduced ERK1/2 activation in vascular smooth muscle cells. Eur J Pharmacol 2007;554:85-91.

15 Zhang S, H Li, SJ Yang: Tribulosin protects rat hearts from ischemia/reperfusion injury. Acta Pharmacol Sin 2010;31:671-678.

-16 Leszczynski D, S Joenvaara, M L Foegh: Protein kinase C-alpha regulates proliferation but not apoptosis in rat coronary vascular smooth muscle cells. Life Sci 1996;58:599-606.

17 Itoh H, S Yamamura, JA Ware: Differential effects of protein kinase C on human vascular smooth muscle cell proliferation and migration. Am J Physiol Heart Circ Physiol 2001;281:H359-H370.

18 Malarkey, K, CM Belham, A Paul, A Graham, A McLees, PH Scott, R. Plevin: The regulation of tyrosine kinase signalling pathways by growth factor and G-protein-coupled receptors. Biochem J 1995;309:361-375.

19 Suh, HW, SS Choi, JK Lee, HK Lee, EJ Han, J Lee: Regulation of c-fos and c-jun gene expression by lipopolysaccharide and cytokines in primary cultured astrocytes: effect of PKA and PKC pathways. Arch Pharm Res 2004;27:396-401.

20 Graham, RM Gilman: Distinct protein targets for signals acting at the c-fos serum response element. Science 1991;251:189-192.

21 Chen, RH, PC Juo, T Curran, J Blenis: Phosphorylation of c-Fos at the C-terminus enhances its transforming activity. Oncogene 1996;12:1493-1502. 